\title{
Catalytic combustion of methane on novel catalysts derived from $\mathrm{Cu}-\mathrm{Mg} / \mathrm{Al}$-hydrotalcites
}

\author{
Zheng Jiang, ${ }^{1}$ Zhengping Hao, ${ }^{1,}{ }^{*}$ Junjie $\mathrm{Yu},{ }^{1}$ Hongxia $\mathrm{Hou},{ }^{1} \mathrm{Chun} \mathrm{Hu}^{1}$ and Jixin $\mathrm{Su}^{2}$ \\ ${ }^{1}$ Research Center for Eco-Environmental Sciences, Chinese Academy of Sciences, Beijing 100085, P.R. China \\ ${ }^{2}$ Environmental Sciences and Engineering School, Shandong University, Ji'nan, 250100, P.R. China
}

Received 17 May 2004; accepted 5 October 2004

\begin{abstract}
Novel $\mathrm{Cu}-\mathrm{Mg} / \mathrm{Al}$ mixed oxides (designated as i-CMAO-800) were prepared by calcinations of $\mathrm{Cu}-\mathrm{Mg} / \mathrm{Al}$-hydrotalcites $\left[\left(\mathrm{Cu}^{2+}+\mathrm{Mg}^{2+}\right) / \mathrm{Al}^{3+}=3\right]$ at $800{ }^{\circ} \mathrm{C}$. Their performance for the catalytic combustion of methane was investigated. The oxides and their precursors were characterized by XRD, TG-DSC, TPR and $\mathrm{N}_{2}$ adsorption/desorption techniques. The results showed that BET surface areas and the stability of the resultant oxides were greatly influenced by the copper contents in hydrotalcite precursors, bringing about difference in their activities for methane catalytic combustion. XRD results indicated that $\mathrm{Cu}$ was highly dispersed in hydrotalcite precursors in case of low copper contents, $(\mathrm{Cu} 40 \mathrm{wt} \%)$. For higher $\mathrm{Cu}$ contents, $\mathrm{Cu}(\mathrm{OH})_{2}$ was formed, and, consequently, a separate phase of $\mathrm{CuO}$ was detected in the oxide catalysts after calcination. As indicated by the TG-DSC results, different decomposition behaviors were observed for various hydrotalcites. Thermal calcination promoted the formation of copper aluminates and segregation of $\mathrm{CuO}$ from the bulk phases. TPR results showed 15CMAO-800 has the highest reduction rate, and the catalytic activities of iCMAO-800 mixed oxides depend on both the reduction rates and the amounts of copper ions in mixed oxides. The catalyst 15-CMAO-800 showed the best performance.
\end{abstract}

KEY WORDS: methane catalytic combustion; copper-containing oxides; hydrotalcites.

\section{Introduction}

Hydrotalcite-like compounds (HTLCs), which are also called anionic clays or Layered Double Hydroxides (LDHs), can be formulated by $\mathrm{M}_{1-x}^{\mathrm{II}} \mathrm{M}_{x}^{\mathrm{III}}(\mathrm{OH})_{2}$ $\left(\mathrm{A}^{n-}\right)_{x / n} \cdot y \mathrm{H}_{2} \mathrm{O}$, where $\mathrm{M}^{\mathrm{II}}=\mathrm{Cu}^{2+}, \mathrm{Ni}^{2+}, \mathrm{Co}^{2+}, \mathrm{Zn}^{2+}$, and $\mathrm{Mn}^{2+} ; \mathrm{M}^{\mathrm{III}}=\mathrm{Al}^{3+}, \mathrm{Fe}^{3+}, \mathrm{Cr}^{3+}, \mathrm{Ga}^{3+}, \mathrm{In}^{3+}, \mathrm{V}^{3+}$, $\mathrm{Ru}^{3+}$, and $\mathrm{Rh}^{3+}$, and $\mathrm{A}^{n-}$ are anions existing in layers [1-5]. Hydrotalcite-like anionic clays are good function materials used as adsorbents, ion exchangers, base catalysts, and potential precursors of mixed oxides for catalytic application, because these compounds can be easily converted into well-mixed oxides via calcination [1-4] In recent years, some new hydrotalcites with substitution of $\mathrm{Mg}^{2+}$ by $\mathrm{Zr}^{4+}, \mathrm{Ti}^{4+}$ or $\mathrm{Sn}^{4+}$ etc, have been synthesized $[1,3,6-8]$. The interesting properties of these materials depend on their specific brucite-like octahedral layered structures. Transition metal oxides derived from hydrotalcite anionic clay precursors have been widely used as heterogeneous catalysts because of their highly uniform distribution of cations, their fairly high surface areas and their great potential to be modified to obtain good catalytic properties [1,3]. HTLCs have been extensively investigated for the development of new environmental friendly catalytic systems, such as steam reforming of methanol for the production of CO-free hydrogen (OSRM), selective catalytic reduction of $\mathrm{NO}_{x}(\mathrm{SCR})$ and selective catalytic oxidization (SCO) of ammonia on $\mathrm{Cu}$-based mixed

\footnotetext{
*To whom correspondence should be addressed.

E-mail: zpinghao@mail.rcees.ac.cn
}

oxides derived from $\mathrm{Cu}$-containing hydrotalcites [9-12]. However, no application of these kinds of materials to the catalytic combustion of natural gas has been reported.

It is well known that catalytic combustion of natural gas is an environment friendly and energy-efficient technology for power and heat generation with ultralow emission of $\mathrm{NO}_{x}, \mathrm{CO}$, and unburned hydrocarbons. Nevertheless, there remains a major problem for the application of catalytic combustion unsettled, namely, the scarcity of robust and stable catalysts for catalytic combustion under severe hydrothermal conditions $[13,14]$. Extensive efforts have been made to develop suitable catalysts and overcome these key obstacles for commercial applications. Generally, supported noble metal oxides, such as palladium and platinum oxides, are excellent catalysts below $800{ }^{\circ} \mathrm{C}$, however they are very expensive and prone to coarsening and deactivation above $800{ }^{\circ} \mathrm{C}$, since they suffer the growth of larger grains by high-temperature sintering $[15,16]$. Copperbased oxide catalysts have comparatively good activities and relatively low costs. Unfortunately, sintering and evaporation of $\mathrm{Cu}$ in both bulk and supported $\mathrm{Cu}$-containing oxides restricted the application of copper catalysts for the catalytic combustion of natural gas $[17,18]$. In view of their excellent properties of oxides derived from hydrotalcites, the $\mathrm{CuMgAlO}$ oxides derived from HTLCs are probably good alternatives of the conventional $\mathrm{Cu}$-based catalysts in catalytic combustion of natural gas, because $\mathrm{Cu}$ can be highly dispersed and stabilized by $\mathrm{Mg} / \mathrm{Al}$ oxides. 
In the present work, $\mathrm{Cu}$-based oxide catalysts have been prepared from $\mathrm{Cu}$-containing hydrotalcites and their performance in catalytic combustion of methane has been studied. It is well known that the formation of good HTLCs structure requires an optimum $\mathrm{M}^{2+} / \mathrm{M}^{3+}$ ratio of approximately 3 , but it is difficult to synthesize pure $\mathrm{Cu}$-containing binary hydrotalcites because of the Jahn-Teller distortion. Fortunately, copper can be incorporated in the HTLC matrix in the presence of other cations to form ternary hydrotalcites $[1,10]$. We have succeeded to prepare a series of $\mathrm{CuMgAl}$-mixed oxides by calcining their hydrotalcite precursors (HTLCs) with $\left(\mathrm{Cu}^{2+}+\mathrm{Mg}^{2+}\right) / \mathrm{Al}^{3+}$ in a molar ratio of 3 . These $\mathrm{CuMgAlO}$ oxides and their precursors were characterized by using XRD and TG-DSC techniques. The reduction behaviors of the resultant oxides were studied by temperature-programmed reduction (TPR) technique.

\section{Experimentals}

\subsection{Catalyst preparation}

Seven copper-magnesium/aluminium hydrotalcites $(\mathrm{Cu}-\mathrm{Mg} / \mathrm{Al}-\mathrm{HTLCs}$, weight percents of $\mathrm{CuO}$ in resultant oxides are $0,5,10,15,20,30,40 \mathrm{wt} \%$ respectively) with $\left(\mathrm{Cu}^{2+}+\mathrm{Mg}^{2+}\right) / \mathrm{Al}^{3+}=3$ were synthesized using the aqueous precipitation method. In brief, they were obtained by co-precipitation from two aqueous solutions $\mathrm{A}$ and $\mathrm{B}$. Solution A contains stoichiometric amounts of $\mathrm{Cu}\left(\mathrm{NO}_{3}\right)_{2} \cdot 6 \mathrm{H}_{2} \mathrm{O}, \mathrm{Mg}\left(\mathrm{NO}_{3}\right) \cdot 6 \mathrm{H}_{2} \mathrm{O}$ and $\mathrm{Al}\left(\mathrm{NO}_{3}\right)_{3} \cdot 9 \mathrm{H}_{2} \mathrm{O}$ in doubly distilled water, whereas solution $\mathrm{B}$ is a freshly prepared $\mathrm{KOH}$ solution. Solutions A and B were simultaneously dropped into $150 \mathrm{~mL}$ doubly distilled water within $1 \mathrm{~h}$ under vigorously stirring, and the solution $\mathrm{pH}$ was kept at $9 \pm 0.5$. The resultant gel was aged with stirring for $4 \mathrm{~h}$. Then the precipitates were subsequently washed and filtered several times to remove $\mathrm{K}^{+}$and other residual anions. Finally, the filtration cakes were dried in oven at $110{ }^{\circ} \mathrm{C}$ for $48 \mathrm{~h}$ to obtain $\mathrm{Cu}-\mathrm{Mg} / \mathrm{Al}-\mathrm{HTLC}$ (designated as iCMA-HTLC). The $\mathrm{Cu}-\mathrm{Mg} / \mathrm{Al}$ mixed oxides catalysts were obtained by calcining $\mathrm{Cu}-\mathrm{Mg} / \mathrm{Al}-\mathrm{HTLCs}$ at $800{ }^{\circ} \mathrm{C}$ for $5 \mathrm{~h}$. The $\mathrm{Cu}-\mathrm{Mg} / \mathrm{Al}$ mixed oxides are denoted as i-CMAO-800, where $\mathrm{i}(0 \leq i \leq 40)$ represents the weight percent of $\mathrm{CuO}$ in the mixed oxides. For example, 5CMAO-800 refers to the catalyst with $\mathrm{CuO} 5$ $\mathrm{wt} \%$ and the calcinations temperature is $800{ }^{\circ} \mathrm{C}$, and $\mathrm{Mg} / \mathrm{Al}$ oxides calcined at different temperatures are denoted as 0CMAO-800.

Platinum/alumina catalyst ( $1 \mathrm{wt} \% \mathrm{Pt}$ loading) was prepared by the impregnation method. Alumina support (pre-calcined at $800^{\circ} \mathrm{C} / 4 \mathrm{~h}$ ) was suspended in an aqueous solution of choloriplatinic acid and oxalic acid $\left(\mathrm{C}_{2} \mathrm{H}_{2} \mathrm{O}_{4}\right)$. After evaporation and calcinations at $500{ }^{\circ} \mathrm{C}$, the sample was reduced with $\mathrm{H}_{2}$ at $500{ }^{\circ} \mathrm{C}$.

\subsection{Catalyst characterization}

\subsubsection{X-ray diffraction}

The crystal structure of the prepared materials was determined by XRD continuous scan analysis using a Japan Rigaku, D/max-RB X-Ray Diffractometer, employing $\mathrm{CuK}_{\alpha}$ radiation $(\lambda=1.5418 \AA$ ), Ni filter, scan speed 4/min, count Mode CPS, voltage $40 \mathrm{kV}$, current $120 \mathrm{~mA}$.

\subsubsection{Surface area measurement}

The specific surface areas of the solid samples were measured by $\mathrm{N}_{2}$ adsorption at $77 \mathrm{~K}$ in a Quantachrome NOVA 1200 Sorptomatic apparatus.

\subsection{3. $T G-D S C$}

The thermal decomposition and stability of iCMAHTLC samples $(40 \mathrm{mg}$ ) were studied by thermogravimetry and differential scanning calorimetry (TG and DSC, Seteram, Labsys ${ }^{\mathrm{TM}}$ ) with high-purity $\mathrm{N}_{2}$ as the carrier gas at a heating rate of $10{ }^{\circ} \mathrm{C} / \mathrm{min} . \quad \mathrm{Al}_{2} \mathrm{O}_{3}$ crucibles were used.

\subsection{4. $T P R$}

Temperature-programmed reduction (TPR) was performed for all the iCMAO-800 catalysts on a conventional TPR apparatus equipped with a thermal conductivity detector (TCD). Catalyst samples $(50 \mathrm{mg}$ each), were inserted in a quartz reactor land sandwiched between two quartz wool plugs. Prior to each TPR run, the catalyst was heated up to $500{ }^{\circ} \mathrm{C}$ under an $\mathrm{O}_{2}$ flow $(40 \mathrm{~mL} / \mathrm{min})$. After a 30 -min pretreatment in $\mathrm{O}_{2}$ flow at $500{ }^{\circ} \mathrm{C}$, the reactor bed temperature was then lowered down to room temperature by keeping the same flow rate of oxygen. Then $\mathrm{N}_{2}$ was fed to the reactor at $30 \mathrm{~mL} / \mathrm{min}$ for $1 \mathrm{~h}$ at room temperature to purge any residual oxygen. The catalyst was then heated to $900{ }^{\circ} \mathrm{C}$ at a constant heating rate of $10^{\circ} \mathrm{C} /$ min using $\mathrm{H}_{2}(5 \mathrm{vol} \%) / \mathrm{N}_{2}(95 \mathrm{vol} \%)$ under a flow rate of $30 \mathrm{~mL} / \mathrm{min}$. $\mathrm{H}_{2}$ concentration was monitored by the TCD detector.

\subsection{Catalytic activity evaluation}

The catalytic activity evaluations for the methane combustion iCMAO-800 s were carried out in a tubular plug flow reactor at atmospheric pressure. Catalysts were activated at $500{ }^{\circ} \mathrm{C}$ for $1 \mathrm{~h}$ in $100 \mathrm{~mL} / \mathrm{min}$ air flow. After cooling down to $100{ }^{\circ} \mathrm{C}$, a mixture of $\mathrm{CH}_{4}: \mathrm{O}_{2}: \mathrm{N}_{2}$ in a volume ratio of $1: 4: 95$ at a total flow rate of $400 \mathrm{~mL} / \mathrm{min}$ passed through the catalyst bed $(0.5 \mathrm{~g}$ catalyst diluted with similar volumed silica). The GHSV was kept approximately $50,000 \mathrm{~h}^{-1}$. The system was heated externally via a tubular furnace regulated via a thermocouple inserted into the catalyst bed. The reactants and products were online analyzed by a GC equipped with FID. The column was a 60/80 Carboxen $1000(15 \mathrm{ft} \times 1.25$ in. s.s. $)$. $\mathrm{CO}$ and $\mathrm{CO}_{2}$ were 
catalytically converted to $\mathrm{CH}_{4}$ by a $\mathrm{Ni}$ catalyst mounted in a catalytic furnace prior to the FID measurements.

The methane conversion rate was calculated based on the integrated GC peak areas. The catalysts activity was characterized by $\mathrm{T}_{10}, \mathrm{~T}_{50}$, and $\mathrm{T}_{90}$ representing the temperatures of methane conversion rates of $10 \%, 50 \%$, and $90 \%$, respectively. The specific activity can be characterized by the turnover frequency (TOF) of methane divided by the mass of $\mathrm{CuO}$ at $500{ }^{\circ} \mathrm{C}$, i.e., $\mu \mathrm{mol} \cdot \mathrm{m}^{-2} \cdot \min ^{-1} \cdot \mathrm{g}^{-1} \mathrm{CuO}$. It is well known that methane combustion follows a pseudo first order kinetic mechanism, so its kinetic equation could be written as $\ln [-\ln (1-\mathrm{x})]=\mathrm{f}(1000 / \mathrm{T})[16]$, where $\mathrm{x}$ is the degree of methane conversion, and $\mathrm{T}$ is the Kelvin temperature at a methane conversion of $\mathrm{x}$. The apparent activation energies (Ea) can be obtained from the $\ln [-\ln (1-x)]$ versus $1 / T$ plots.

\section{Results and discussion}

\subsection{Physicochemical characterization}

\subsubsection{X-ray diffraction analysis of iCMA-HTLCs and mixed oxides derived from HTLCs}

The X-ray diffraction patterns of HTLCs (dried at $110^{\circ} \mathrm{C}$ ) were shown in figure 1 . All the patterns show sharp and symmetric reflection at small diffraction angles, as well as weak and asymmetric reflections at larger diffraction angles, which are characteristic diffraction patterns of hydrotalcites (JCPDS 22-700). However, slight differences were observed for samples with different $\mathrm{Cu}$-contents. Only hydrotalcite phases were detected in the $\mathrm{Cu}$-containing 5-30CMA-HTLCs samples. In these five HTLCs catalysts, copper was incorporated into the hydrotalcite structures thoroughly and was well dispersed. However, in 40CMA-HTLC at $35.5^{\circ}$ and $38.7^{\circ}$, an independent $\mathrm{Cu}(\mathrm{OH})_{2}$ phase appeared besides the hydrotalcite. Moreover, the characteristic peaks related

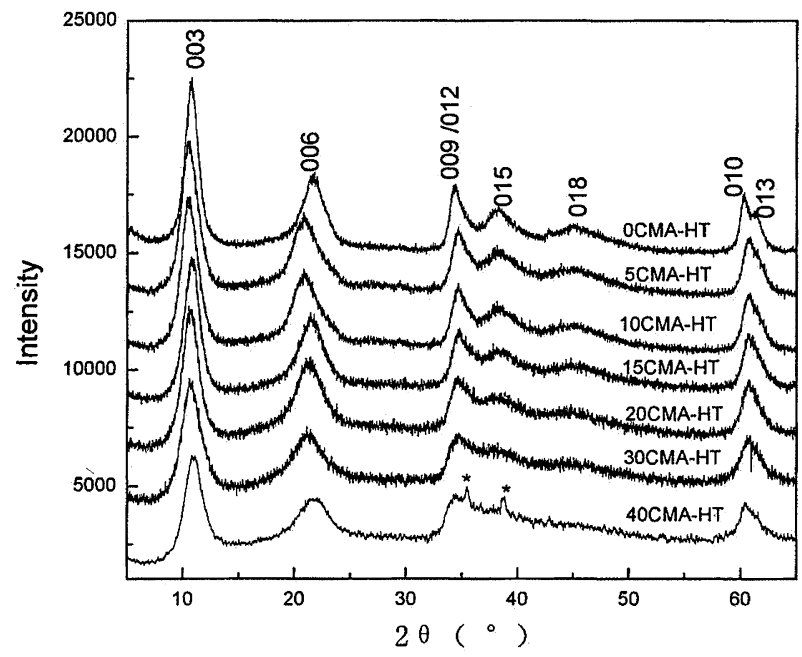

Figure 1. XRD patterns of iCMA-HTLCs $\left({ }^{*} \mathrm{Cu}(\mathrm{OH})_{2}\right)$. to (003), (006) and (009) planes become broader and move to higher $2 \theta$ with an increase in $\mathrm{Cu}$ content, and the peaks of (013) merged with (010) for $\mathrm{Cu}$-containing samples. Further increase in copper content in CMA-HTLCs led to further broadening and weakening of the peaks of (015) and (018). Therefore, in order to obtain pure and homogeneously dispersed $\mathrm{Cu}-\mathrm{Mg} / \mathrm{Al} \mathrm{HTLCs}$, the $\mathrm{CuO}$ content in the final oxides should be controlled below $40 \mathrm{wt} \%$. The weaker and broader diffraction peaks at high diffraction angles can be explained by the JohnTeller effect of $\mathrm{Cu}^{2+}$ ion owing to its larger ionic radius in comparison with $\mathrm{Mg}^{2+}[20,21]$.

Figure 2 describes the XRD patterns of HTLCs after calcination at $800{ }^{\circ} \mathrm{C}$ for $5 \mathrm{~h}$. The HTLC phases were completely destroyed and new oxide derivatives were formed from HTLCs. The three dominant peaks with the $2 \theta$ angle centered at $37^{\circ}, 42^{\circ}$ and $62.3^{\circ}$ for iCMAO-800 were ascribed to periclase (MgO, JCPDS 431022). A small diffraction peak assigned to spinel phase $\left(\mathrm{MgAl}_{2} \mathrm{O}_{4}\right.$ JCPDS 21152) appeared at $65^{\circ}$, whereas other peaks related to spinel could not be identified because of the interference of stronger diffractions of periclase. With increases of copper content in iCMAO-800, the diffraction intensities of peaks ascribed to periclase were reduced, but the peaks of spinel became much stronger. The stronger spinel diffractions may be caused by the superimposed $\mathrm{CuAl}_{2} \mathrm{O}_{4}$ inverse spinels, since their diffractions are very similar to $\mathrm{MgA}_{2} \mathrm{O}_{4}$. Because of the relatively low formation temperature of $\mathrm{CuAl}_{2} \mathrm{O}_{4}$, the enhanced diffractions of spinels were most likely caused by the increases of $\mathrm{CuAl}_{2} \mathrm{O}_{4}$ spinels rather than $\mathrm{MgAl}_{2} \mathrm{O}_{4}$. On the other hand, the partial substitution of $\mathrm{Mg}$ by $\mathrm{Cu}$ promoted the formation of $\mathrm{MgAl}_{2} \mathrm{O}_{4}$ spinel too. Moreover, since the diffraction peaks of periclase and spinel phase appeared around $43^{\circ}$, the diffraction intensity of spinels was not weakened at a decrease of $\mathrm{Mg}^{2+}$ content in HTLCs, and spinel epitaxially grew along the $\mathrm{MgO}$ periclase surface [22].

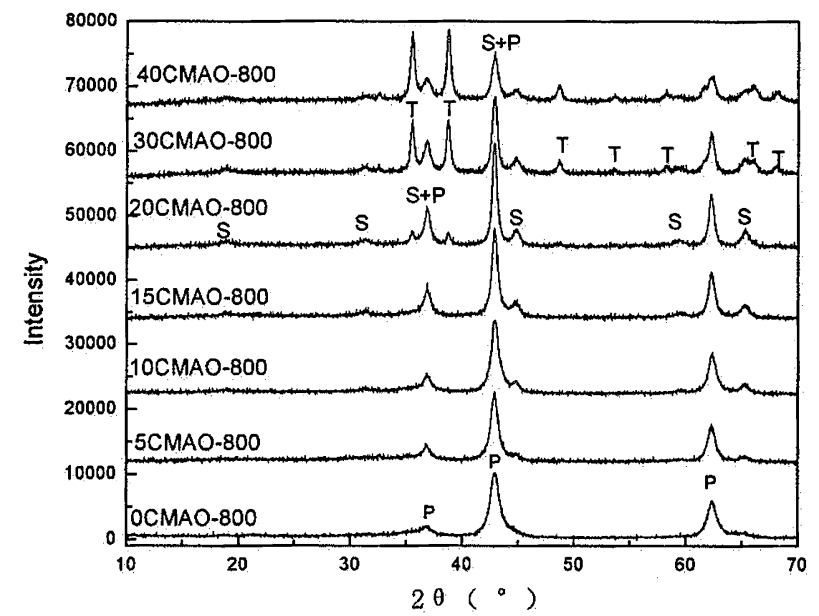

Figure 2. XRD patterns of CMAO oxides calcined at $800{ }^{\circ} \mathrm{C}$ $(\mathrm{S}=$ spinel, $\mathrm{P}=$ periclase, $\mathrm{T}=$ tenorite $)$. 
Table 1

Activities of CMAO catalysts calcined at $800{ }^{\circ} \mathrm{C}$ for $5 \mathrm{~h}$

\begin{tabular}{lccccccc}
\hline Samples & $\begin{array}{c}T_{10} \\
\left({ }^{\circ} \mathrm{C}\right)\end{array}$ & $\begin{array}{c}T_{50} \\
\left({ }^{\circ} \mathrm{C}\right)\end{array}$ & $\begin{array}{c}T_{90} \\
\left({ }^{\circ} \mathrm{C}\right)\end{array}$ & $\begin{array}{c}\mathrm{SSA} \\
\left(\mathrm{m}^{2} / \mathrm{g}\right)\end{array}$ & $\mathrm{TOF}^{\mathrm{a}}$ & $\begin{array}{c}\mathrm{TOF}^{\mathrm{b}} \\
/ \mathrm{CuO}\end{array}$ & $\begin{array}{c}E_{\mathrm{a}}^{\mathrm{c}} \\
(\mathrm{KJ} / \mathrm{mol})\end{array}$ \\
\hline Silica & 925 & - & 950 & - & 0 & - & 285 \\
0CMAO & 628 & 742 & 803 & 138 & 0.06 & - & 194 \\
5CMAO & 513 & 591 & 686 & 125 & 0.21 & 2.12 & 113 \\
10CMAO & 516 & 582 & 652 & 110 & 0.21 & 1.04 & 144 \\
15CMAO & 432 & 521 & 617 & 84 & 1.34 & 4.48 & 99 \\
20CMAO & 443 & 533 & 625 & 60 & 1.46 & 3.66 & 89 \\
30CMAO & 436 & 520 & 639 & 57 & 2.05 & 3.41 & 50 \\
40CMAO & 400 & 483 & 606 & 59 & 3.25 & 4.06 & 51 \\
$\mathrm{Pt}_{\mathrm{Al}} \mathrm{O}_{3}$ & 425 & 485 & 550 & 122 & 4.28 & - & 104 \\
\hline
\end{tabular}

${ }^{\mathrm{a}} \mathrm{TOF}=$ Turnover frequency, calculation at $500{ }^{\circ} \mathrm{C}, \mu \mathrm{mol} \cdot \mathrm{m}^{-2}$. $\min ^{-1}$.

${ }^{\mathrm{b}} \mathrm{TOF}^{\mathrm{b}} / \mathrm{CuO}=$ Turnover frequency per gram $\mathrm{CuO}$, calculation at $500{ }^{\circ} \mathrm{C}, \mu \mathrm{mol} \cdot \mathrm{m}^{-2} \cdot \mathrm{min}^{-1} \cdot \mathrm{g}^{-1} \mathrm{CuO}$.

${ }^{\mathrm{c}} E_{a}$ calculated from methane conversion below $40 \%$.

Another notable phenomenon is that well-crystallized $\mathrm{CuO}$ (tenorite) diffraction signals were detected, if copper oxide content exceeded $20 \mathrm{wt} \%$ in iCMA- 800
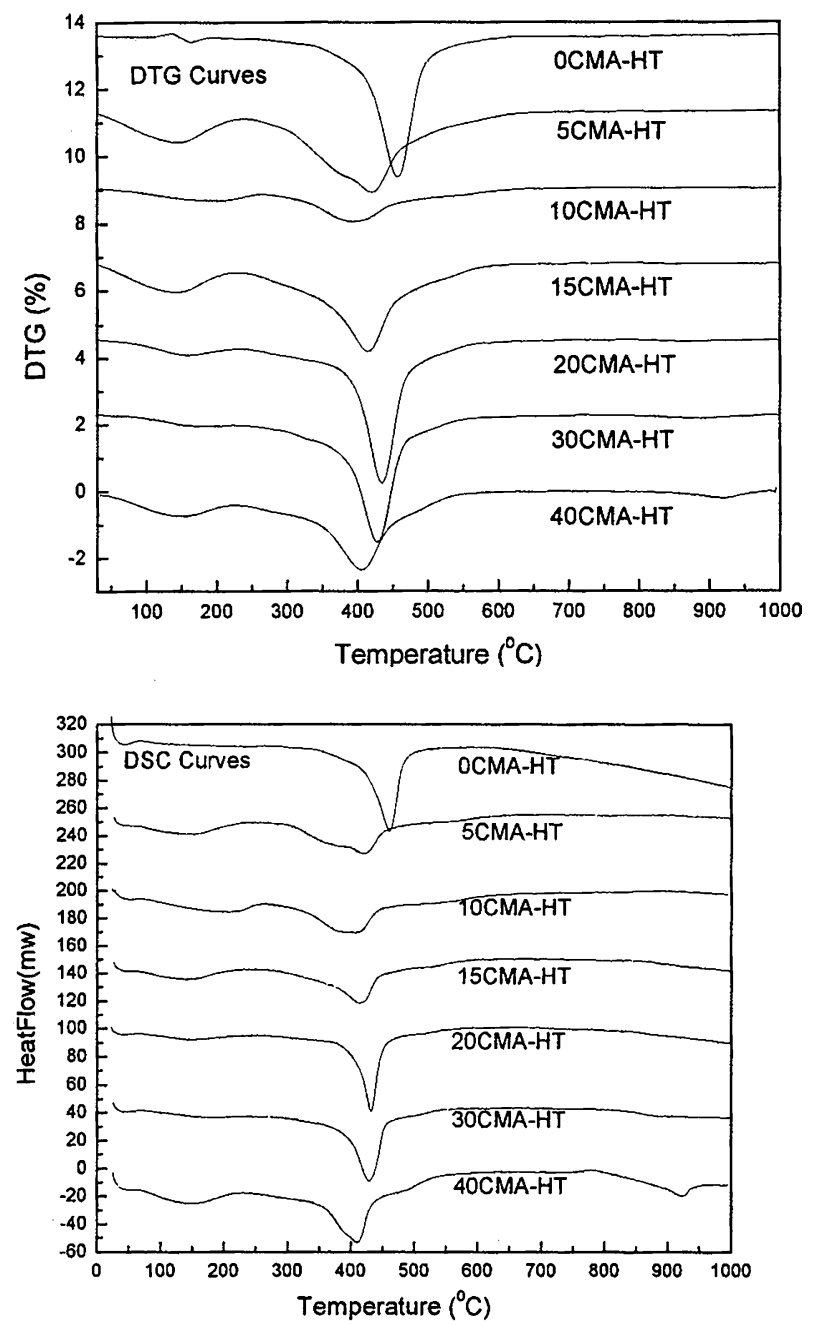

Figure 3. TG-DSC profiles of iCMA-HTLC . $_{\text {. }}$.

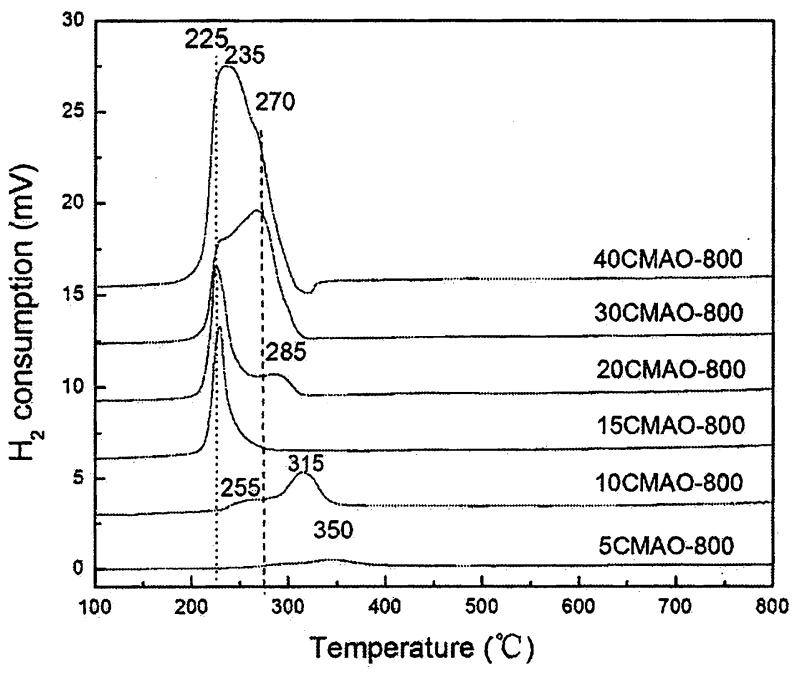

Figure 4. TPR profiles of iCMAO-800.

catalysts. However, no teronite phases were detected, if $\mathrm{CuO}$ content was below $15 \mathrm{wt} \%$. One possible reason was that the incorporation of copper into the $\mathrm{MgO}$ matrix and the formation of $\mathrm{CuAl}_{2} \mathrm{O}_{4}$ inverse spinel crystallites led to the high dispersion of $\mathrm{CuO}$ in the complex oxides. $\mathrm{Mg}^{2+}$ in the mixed oxides might restrict clustering and agglomeration of $\mathrm{CuO}$. Because the oxides were calcined under the same conditions, the differences in diffraction patterns should result from the content of copper in precursors.

\subsubsection{BET areas of $i C M A-800$ oxides}

The specific surface areas (SSA) of iCMA-800 oxides and $\mathrm{Pt} / \mathrm{Al}_{2} \mathrm{O}_{3}$ were listed in table 1 . The composition of the samples affects their SSA. The SSA changes of the mixed oxides corresponded well with their phase changes as indicated by their XRD patterns. The SSA of the mixed oxides decreased quite steadily with an increase in $\mathrm{Cu}$ content (as shown in figure 6) exceeding $20 \mathrm{wt} \%$. At the mean time, the spinel peaks became intensified, as shown in figure 3. Consequently, an increment of $\mathrm{Cu}$ in hydrotalcite precursors caused a decrease of SSA in iCMAO-800, in other words, $\mathrm{CuO}$ in calcined oxides induced partial sintering of such samples but $\mathrm{Mg}^{2+}$ can depress sintering.

\subsubsection{TG-DSC analysis of iCMA-HTLCs}

Thermal transformation of $\mathrm{Mg} / \mathrm{Al}$ hydrotalcite to oxides has been described elsewhere [23]. Generally, during calcination a typical two-stage thermal-gravity loss can be ascribed to the release of interlayer water and anions, as well as the simultaneous loss of interlayer hydroxyl groups and other anions. Elimination of hydroxyl groups was completed at higher temperatures and caused sintering of the resultant oxides. Thermal decomposition characteristics of the $\mathrm{Cu}-\mathrm{Mg} / \mathrm{Al}$ hydrotalcite-like precursors and $\mathrm{Mg} / \mathrm{Al}-\mathrm{NO}_{3}^{-}$hydrotalcite into oxides are compared in figure 3 . The two-stage weight 
loss and the corresponding heat absorption of all HTCLs except 40CMA-HTLCs are shown in these DTG and DSC profiles respectively. The interlayer water released at $150-250{ }^{\circ} \mathrm{C}$, and the temperature for water loss lowered as their copper content increased. In the course of subsequent heating at $300-550{ }^{\circ} \mathrm{C}$, hydroxyl and nitrate groups were simultaneously transformed into water and $\mathrm{NO}_{x}$, and the layered structures of hydrotalcites collapsed. A disordered $\mathrm{MgO}$ periclase phase was formed then predominantly. High $\mathrm{Cu}$ content (above $30 \mathrm{wt} \%$ ) caused the formation of new mixed phases ( $\mathrm{CuO}$ phases) after calcination around $500{ }^{\circ} \mathrm{C}$, as shown in their XRD patterns [24]. Similar to the release of interlayer water, with an increase in the copper content of precursors, the secondstage decomposition temperature became lower and the temperature range broader. No DTG and DSC signals were detected during heating at $800-950{ }^{\circ} \mathrm{C}$ for 0-30CMA-HTLCs, and these temperature ranges were related to the phase transitions from HTLCs to spinels. The evidence of $\mathrm{CuO}$ decomposition in 40CMA-HT was its weight loss and heat release at $900{ }^{\circ} \mathrm{C}$. The separated $\mathrm{CuO}$ phase in CMAO oxides was not stable as compared with the highly dispersed copper in the catalyst crystal structures. These findings are fairly consistent with A. Alejandre's conclusion on the decomposition of $\mathrm{Cu} / \mathrm{Al}$-hydrotalcite, who ascribed this weight loss to the transition of $\mathrm{CuO}$ to the more stable $\mathrm{Cu}_{2} \mathrm{O}$ at elevated temperatures [21]. It can be conclude that an appropriate copper content $(15 \mathrm{wt} \%$ of $\mathrm{CuO})$ is a key factor for the development of stable and good $\mathrm{Cu}$-containing iCMAO-800 oxide catalysts.

\subsubsection{TPR analysis of iCMAO-800 catalysts}

Results of temperature-programmed reduction were shown in figure 4. Different reduction behaviors could be observed depending on copper contents in oxides, except the sample OCMAO-800 which was not shown in figure 4 . Kovanda et al. [25] detected a prevailing peak around $700{ }^{\circ} \mathrm{C}$, which was assigned by the authors to the reduction of trace impurities in raw material [25]. Inconsistency in results of different authors might stem from different precursors selected and different purities of the $\mathrm{Mg} / \mathrm{Al}$ oxide used. With an increase of copper content in HTLC precursors, several superimposed and relatively intense peaks appeared, and the reduction temperature gradually shifted to a lower range, but the extent of reduction significantly enhanced. There was only one diffuse $\mathrm{H}_{2}$ consumption peak centered at $350{ }^{\circ} \mathrm{C}$ for $5 \mathrm{CMAO}-800$, initialed at $230{ }^{\circ} \mathrm{C}$ and ended around $390{ }^{\circ} \mathrm{C}$, which is higher than that of the bulk $\mathrm{CuO}$ reduction. This peak could be ascribed to the highly dispersed $\mathrm{Cu}^{2+}$ in bulk periclase or copper aluminate structure, because the strong affinity of $\mathrm{CuO}$ and supports resulted in higher reduction temperature [26]. For the sample 10CMAO-800, the two peaks centered at 255 and $315{ }^{\circ} \mathrm{C}$ corresponded to highly dispersed copper ions in the supported catalysts and in the bulk copper aluminates, respectively [21]. For the 15CMAO-800, the reduction behavior was quite different from others, and an intense and steep peak centered at $228^{\circ} \mathrm{C}$ was observed. The low-temperature $\left(225^{\circ} \mathrm{C}\right)$ reduction characteristics of 20-40CMAO-800 samples were very similar to $15 \mathrm{CMAO}-800$, except the satellite peak at $285{ }^{\circ} \mathrm{C}$ for 20CMAO-800 associated with the isolated copper oxide particulate on periclase and spinels. The broad overlapping peaks shown between 200 and $300{ }^{\circ} \mathrm{C}$ for 30CMAO-800 and 40CMAO-800 samples can be disintegrated into three peaks centered at 225,235 and $270{ }^{\circ} \mathrm{C}$, respectively. The peaks at 225 and $235^{\circ} \mathrm{C}$ can be assigned to highly dispersed $\mathrm{CuO}$ particles supported on the surface of periclase and $\mathrm{CuAl}_{2} \mathrm{O}_{4}$ spinel. According to Severino et al. [27] the reducibility of surface copper aluminate was lower than that of copper oxide, and the reduction of copper aluminates takes place in the range of 230-270 ${ }^{\circ} \mathrm{C}$. Thus, the last peak at $270{ }^{\circ} \mathrm{C}$ may be attributed to the reduction of the bulk $\mathrm{CuO}$ in the mixed oxides [26]. Although the extent of reduction of 15CMAO-800 was lower than that of 20-40CMAO-800, its $\mathrm{H}_{2}$ consumption peak was steeper, implying the rapid reduction of copper ions. In other words, the specific activity per unit copper ion in 15CMAO-800 was comparative to the later.

\subsection{Catalytic activity of methane combustion on iCMAO-800 catalysts}

In the conventional $\mathrm{Cu}$ catalysts, alumina is usually used as the catalyst support. Over $700{ }^{\circ} \mathrm{C}$, evaporation of $\mathrm{CuO}$ and interaction between copper and alumina occur, leading to partial deactivation. Alternative support material can eliminate copper-support interaction. For example, P. Artizzu et al. [18] have improved methane combustion by using a mangnesium aluminate support for the $\mathrm{CuO}$ catalysts. However, it could not prevent

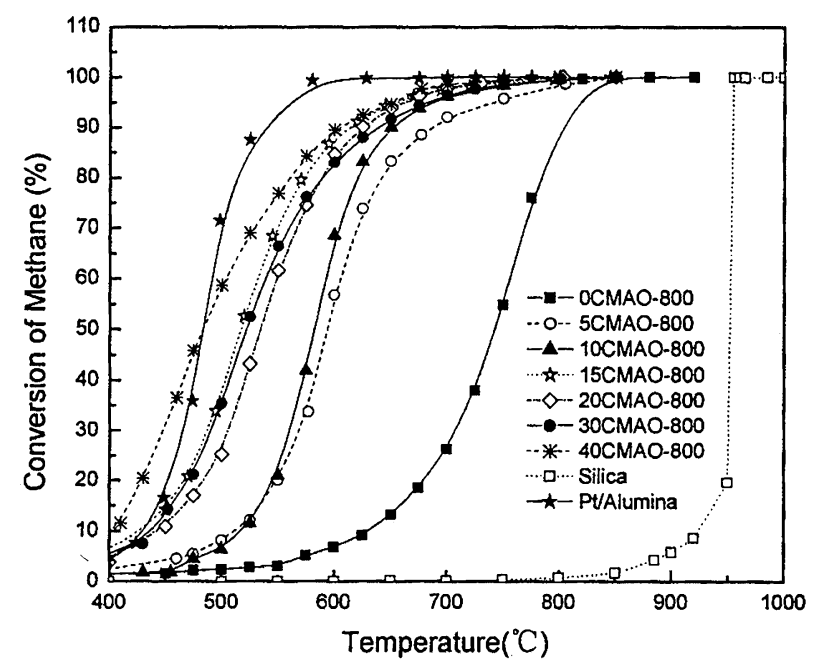

Figure 5. Temperature dependence of methane conversion on iCMAO-800. 


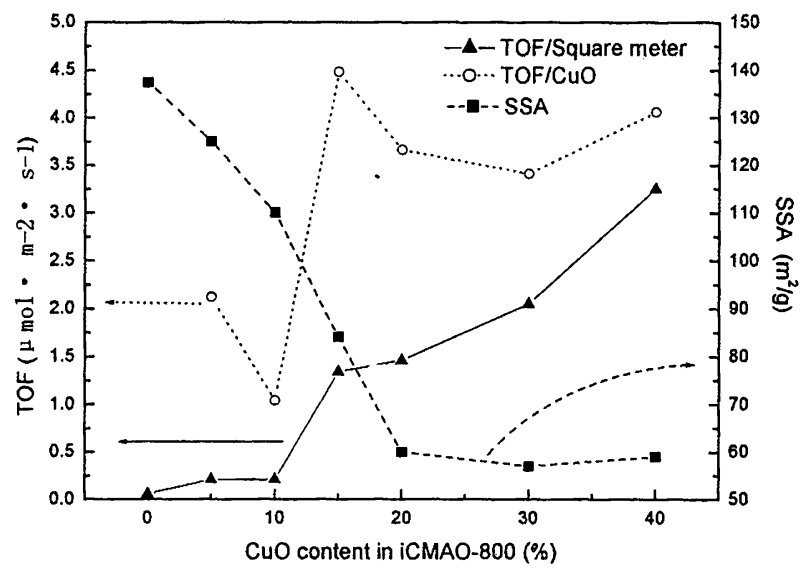

Figure 6. The effect of the $\mathrm{CuO}$ contents on the specific surface area (SSA) and specific activities of iCMAO-800.

evaporation of copper at elevated temperatures. Oxides derived from $\mathrm{Cu}-\mathrm{Mg} / \mathrm{Al}$ hydrotalcite may satisfy this stability requirement, since copper exists in the bulk of mixed oxides as copper aluminate.

The performance of iCMAO-800 catalysts for methane combustion was compared with that of noncatalytic thermal combustion of methane. As showed in figure 5, the conversion rate of methane can be enhanced by increase the reaction temperature. Judging from the characteristic activity data listed in table 1, incorporation of $\mathrm{Cu}$ into the catalysts greatly improved its activity for methane combustion, and the activity improvement depends upon the copper content. Furthermore, the light-off activities of copper-rich catalysts were comparable to the conventional $\mathrm{Pt} /$ alumina catalyst, though their total conversion temperatures were higher than that of $\mathrm{Pt}$ /alumina. In spite of the decrease in surface area with increase of the copper content, the light-off activity for methane combustion has been improved, i.e., the $\mathrm{T}_{10}$ decreased with increasing $\mathrm{Cu}$ content of iCMAO-800 catalysts. However, considering the specific activity and utility of copper for methane combustion, 15CMAO-800 was highest efficient catalyst among these catalysts. Even though 40CMAO-800 owned highest apparent activity, its lower SSA and thermal stability made it was not suitable for practical application.

No $\mathrm{CO}$ was detected in $\mathrm{CH}_{4}$ combustion on iCMAO$800(i>0)$. However, on 0CMAO-800, the higher CO concentration $200 \mathrm{ppm}$ was observed, which was produced from gas phase combustion and far lower than that $(1400 \mathrm{ppm})$ on silica. The results indicated there was no thermal combustion occurred on iCMAO-800 $(i>0)$, whereas slight contribution of gas phase combustion occurred on 0CMAO-800. Generally, $\mathrm{Mg}^{2+}$ and $\mathrm{Al}^{3+}$ are all inactive for methane combustion, but methane combustion on 0CMA-800 was complete around $800{ }^{\circ} \mathrm{C}$ after light-off at $630^{\circ} \mathrm{C}$, which significantly differed from methane thermal combustion on silica, therefore, methane mainly occurred catalytic combustion on 0CMA-800. Moreover, 0CMAO-800 was much more active than $\mathrm{MgAl}_{2} \mathrm{O}_{4}$ for combustion as reported by P. Artizzu et al. [18], that methane conversion was only $30 \%$ on $\mathrm{MgAl}_{2} \mathrm{O}_{4}$ but over $50 \%$ on $0 \mathrm{CMAO}-800$ at $750{ }^{\circ} \mathrm{C}$. The possible reason is $0 \mathrm{CMAO}-800$ catalyst having much higher SSA $\left(110 \mathrm{~m}^{2} / \mathrm{g}\right)$ than $\mathrm{MgAl}_{2} \mathrm{O}_{4}$ $\left(47 \mathrm{~m}^{2} / \mathrm{g}\right)$.

Although the catalytic activity of these catalysts is not directly proportional to the total amount of copper as shown in figure 6 , their activities for methane combustion are reasonably related to the amount of the "reducible $\mathrm{Cu}$ ". The appropriate copper content in the final oxides is around $15 \mathrm{wt} \%$. Both TPR results and reaction data confirmed this point.

\section{Conclusions}

A series of $\mathrm{Cu}-\mathrm{Mg} / \mathrm{Al}$ mixed oxide catalysts derived from calcined $\mathrm{Cu}$-containing hydrotalcite precursors with $\mathrm{M}^{2+} / \mathrm{M}^{3+}=3$ were prepared, using co-precipitation and thermal evolution methods. TG-TSC, XRD, BET, and TPR techniques were used for catalyst characterization.

$\mathrm{Cu}$ was highly dispersed in hydrotalcite precursors in case of low copper contents $(\mathrm{Cu}<40 \mathrm{w} \%)$. For higher $\mathrm{Cu}$ contents, $\mathrm{Cu}(\mathrm{OH})_{2}$ was formed, and, consequently, a separate phase of $\mathrm{CuO}$ was detected in the oxide catalysts after calcination. Thermal calcination promoted the formation of copper aluminates and segregation of $\mathrm{Cu}$ ions from the bulk phases.

The catalytic activity for methane combustion is closely related to the copper species and $\mathrm{Cu}$ content in calcined oxides, and, magnesium presented in the oxides enhanced their stability though decreased their reducibility. The appropriate copper content is around $15 \mathrm{wt} \%$.

\section{Acknowledgments}

Financial funds from the Chinese Natural Science Foundation (project no. 20322201). The Knowledge Innovation Funds of the Chinese Academy of Sciences (key project KZCX3-SW-430) and the Asian Regional Research Programme on Environmental Technology (ARRPET) sponsored by the Swedish International Development for Research Cooperation Agency (SIDA) are gratefully acknowledged.

\section{References}

[1] F. Cavani, F. Trifiro and A. Vaccari, Catal. Today 11 (1991) 173.

[2] J.M.L. Nieto, A. Dejoz and M.I. Vazquez, Appl. Catal. 132 (1995) 41.

[3] S. Velu and C.S. Swamy, Catal. Lett. 40 (1996) 265.

[4] M. Belloto, B. Rebours, O. Clause, J. Lynch, D. Bazin and E. Elkaim, J. Phys. Chem. 100 (1996) 8527.

[5] C. Depege, L. Bigey, C. Forano, A. de Roy and J.P. Besse, J. Solid State Chem. 126 (1996) 314. 
[6] S. Velu, V. Ramaswamy, A. Ramani, B.M. Chanda and S. Sivasanker, Chem. Commun. (1997) 2107.

[7] S. Velu, K. Suzuki, T. osaki, F. Ohashi and S. Tomura, Mater. Res. Bull. 34 (1999) 1707.

[8] U.P. Pillai and E. Sahle-Demessie, J. Mol. Catal. A 191 (2003) 93.

[9] S. Velu, K. Suzuki and T. Osaki, Chem. Commun. (1999) 2341.

[10] S. Velu and K. Suzuki, J. Phys. Chem. B. 106 (2002) 12737.

[11] L. Chmielarz, P. Klustrowski, A.R. Lasocha and R. Dziembaj, Appl.Catal. B 35 (2002) 195.

[12] M. Trombetta, Langmuir 13 (1997) 4628.

[13] L. Pfefferle and W. Pfefferle, Catal. Rev. 29 (1987) 219.

[14] P.O. Thevenin, A.G. Ersson, H.M.J. Kusar, P.G. Menon and S.G. Jaras, Appl. Catal. A 212 (2001) 189.

[15] Jon G. McCarty, Nature 403 (2000) 35.

[16] P. Forzatti and G. Groppi, Catal. Today 54 (1999) 165.

[17] P. Artizzu, N. Guilhaurne, E. Garbowski, Y. Brull'e and M. Primet, Catal. Lett. 51 (1998) 69.
[18] P. Artizzu, E. Garbowski, M. Primet, Y. Brulle and J. Saint-Just, Catal. Today 47 (1999) 83.

[19] V.C. Belessi, A.K. Ladvos and P.J. Pomonis, Appl. Catal. B 31 (2001) 183.

[20] W.T. Reichle, Solid State Ionics 22 (1986) 135.

[21] A. Alejandre, F. Medina, P. Salagre, X. Correig and J.E. Sueiras, Chem. Mater. 11 (1999) 939.

[22] S. Narayanan and K. Krishna, Chem.Commun. (1997) 1991.

[23] M. Bellotto, B. Rebours, O. Clause, J. Lynch, D.E. Bazin and Elkaim, J. Phys.Chem. 100 (1996) 8535.

[24] J.J. Yu, Z. Jiang, Z.P. Hao, S.F. Kang and C. Hu, Chin. Chem. phys. (2004) Accepted.

[25] F. Kovanda, K. Jiratova, J. Rymes and D. Kolousek, Appl. Clay Sci. 18 (2001) 71.

[26] K.T. Jacob and C.B. Alcock, J. Am. Ceram. Soc. 38 (1975) 192.

[27] F. Severino, J. Brito and J. Laine, et al. J. Catal. 102 (1986) 172. 